University of Nebraska - Lincoln

DigitalCommons@University of Nebraska - Lincoln

1995

Relationship-Based Approach to Leadership: Development of

Leader-Member Exchange (LMX) Theory of Leadership over 25

Years: Applying a Multi-Level Multi-Domain Perspective

George B. Graen

University of Cincinnati

Mary Uhl-Bien

University of Nebraska-Lincoln, mbien2@unl.edu

Follow this and additional works at: https://digitalcommons.unl.edu/managementfacpub

Part of the Management Sciences and Quantitative Methods Commons

Graen, George B. and Uhl-Bien, Mary, "Relationship-Based Approach to Leadership: Development of Leader-Member Exchange (LMX) Theory of Leadership over 25 Years: Applying a Multi-Level MultiDomain Perspective" (1995). Management Department Faculty Publications. 57.

https://digitalcommons.unl.edu/managementfacpub/57

This Article is brought to you for free and open access by the Management Department at DigitalCommons@University of Nebraska - Lincoln. It has been accepted for inclusion in Management Department Faculty Publications by an authorized administrator of DigitalCommons@University of Nebraska - Lincoln. 


\title{
Relationship-Based Approach to Leadership: Development of Leader-Member Exchange (LMX) Theory of Leadership over 25 Years: Applying a Multi-Level Multi-Domain Perspective
}

\author{
George B. Graen \\ University of Cincinnati \\ Corresponding author - International Leadership Center \\ College of Business Administration, \\ University of Cincinnati, Cincinnati, OH 45221-0020 \\ Mary Uhl-Bien \\ University of Alaska - Anchorage
}

\begin{abstract}
Research into Leader-Member Exchange (LMX) theory has been gaining momentum in recent years, with a multitude of studies investigating many aspects of LMX in organizations. Theoretical development in this area also has undergone many refinements, and the current theory is far different from the early Vertical Dyad Linkage (VDL) work. This article uses a levels perspective to trace the development of LMX through four evolutionary stages of theorizing and investigation up to the present. The article also uses a domains perspective to develop a new taxonomy of approaches to leadership, and LMX is discussed within this taxonomy as a relationship-based approach to leadership. Common questions and issues concerning LMX are addressed, and directions for future research are provided.
\end{abstract}

\section{Introduction}

Since its inception over 25 years ago, the conceptualization of Leader-Member Exchange (LMX) theory (Dansereau, Graen, \& Haga, 1975; Graen \& Cashman, 1975; Graen, 1976; Graen, Novak \& Sommerkamp, 1982; Graen \& Scandura, 
1987; Graen \& Uhl-Bien, 1991; Graen \& Wakabayashi, 1994) has undergone many refinements. What began as an alternative to average leadership style (Vertical Dyad Linkage) (Dansereau, Graen, \& Haga, 1975) has progressed to a prescription for generating more effective leadership through the development and maintenance of mature leadership relationships (Graen \& Uhl-Bien, 1991). In the process, as elaborated in this article, the theory has been considered from several levels of analysis: from a focus on differences within groups (group-level effect) to a focus on dyads regardless of groups (dyad-level effect) to most recently a focus on the combination of dyads into groups and networks (dyads within groups effect). Examination of the theory from each of these levels raises many unique and important issues and questions, the answers to which will likely advance our thinking about leadership. Thus, the present article adopts a levels perspective to trace the evolution of LMX and provide readers with an overview of the most current developments in LMX theory and research.

In order to do this, we first attempt to explain where LMX fits into leadership theory by describing LMX in terms of an overall taxonomy of leadership approaches. This taxonomy was generated by a consideration of levels issues and classifies leadership theories according to the domain addressed by the three facets of leadership (e.g., leader, follower, relationship). Discussion of the taxonomy and where LMX fits into it is followed by a brief review of the four stages in the evolution of LMX (and the level of analysis in each) and a summary of current theorizing and empirical support for the model. Based upon this discussion, suggestions for research and practice are offered.

\section{Classifying Leadership Theory}

Dansereau and colleagues (Klein, Dansereau, \& Hall, 1994; Dansereau, Alutto, \& Yammarino, 1984) and Rousseau (1985) have made compelling arguments for the importance of considering levels of analysis in theory development. In particular, Klein et al. (1994) argue that "greater attention to levels issues will increase the clarity, testability, comprehensiveness, and creativity of organizational theories" (p. 224). Nowhere may this be more true than in the area of leadership. Despite many years of leadership research and thousands of studies, we still do not have a clear understanding of what leadership is and how it can be achieved. In particular, there appear to be many theories that address different aspects of leadership but little cohesion among the theories that help us understand how they all tie together.

Part of the ambiguity in the leadership area may be due to the fact that taxonomies of approaches to leadership study have been inadequately examined from a levels perspective. Development of a taxonomy using such a perspective may provide the clarity and cohesion currently missing in leadership research.

For example, as new leadership theories emerge, attempts to classify them into general categories of approaches are becoming more difficult. Traditionally, these categorizations (e.g., trait approaches, behavioral approaches, contingency/ situational approaches; see Yukl, 1989) have focused primarily on characteristics of the supervisor (e.g., traits, behaviors, styles, etc.) and how these characteristics make him/ her either effective or ineffective in different situations. Because this typology does not specifically acknowledge other levels in which leadership operates (such as the follower or the leadership relationship), determining where 
approaches that address these levels fit into our overall thinking about leadership is difficult. One result of this is potential confusion and disagreement among scholars about what we do know about leadership and about how models that do not lit neatly into this typology (such as Leader-Member Exchange or empowerment models) should be categorized. This may also create difficulties for textbook writers and teachers attempting to present a meaningful categorization of the myriad leadership theories to students. Moreover, this typology may lead to incomplete research designs since emphasis is on one domain, the leader, without equal and concurrent emphasis on other domains (e.g., the follower or the dyadic relationship). Thus, to obtain a more balanced understanding of the leadership process, a taxonomy needs to be developed that more clearly reflects the multi-faceted nature of leadership situations.

One way to do this is to expand our classification system beyond the leader to include other levels involved in leadership (as shown in Figure 1). Such levels are the follower (Meindl, Erlich, \& Dukerich, 1985; Kelley, 1988; Hollander, 1978) and the dyadic relationship between the leader and follower (Hollander, 1978; Graen \& Uhl-Bien, 1991). Since leadership involves all three of these domains, studies of leadership could address each domain singularly (e.g., models that focus on the leader such as trait or behavioral approaches; models that focus on the follower such as empowerment approaches; or models that focus on the relationship, such as LMX) or multiple domains in combination (e.g., situational approaches that address the leader, the follower, and the relationship in combination). In order to obtain the most comprehensive representation of the leadership process, however, the taxonomy suggests that more studies take on a multiple domain perspective (as suggested by Rousseau [19851 and Klein et al. [ 19941). This is because even though use of one domain may generate specific and valuable information about that domain, relevant critical aspects of other domains may be overlooked, thereby reducing the predictive power and generalizability of the information. Therefore, careful sampling from multiple domains within the same investigation should account for more of the potential leadership contribution, and thus increase the predictive validity and practical usefulness of our studies.

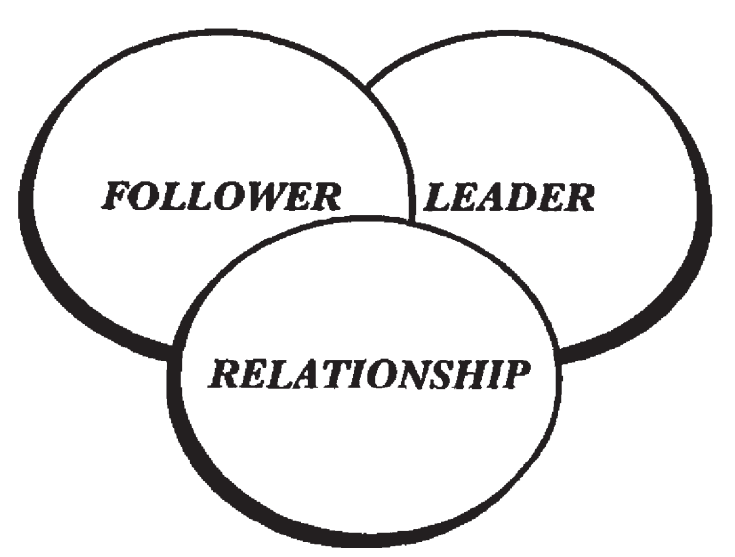

Figure 1. The Domains of Leadership 
Table 1. Studies Using a Three Domain Approach to Leadership and Innovative Behavior

\begin{tabular}{lccc}
\hline & $\begin{array}{c}\text { Basu (1991) } \\
\text { Printing Operators } \\
(N=181)\end{array}$ & $\begin{array}{c}\text { Tierney }(1992) \\
\text { Chemical Researchers } \\
(N=145)\end{array}$ & $\begin{array}{c}\text { Scott }(1993) \\
\text { Steel Researchers } \\
(N=189)\end{array}$ \\
\hline Correlation: & .03 & .05 & .03 \\
Charisma & $.22^{* *}$ & $.29^{* *}$ & $.19^{* *}$ \\
LMX & $.25^{* *}$ & $.37^{* *}$ & $.35^{* * *}$ \\
Follower & & & $-.29^{* *}$ \\
R Beta: & $-.35^{* *}$ & $-.18^{*}$ & $.36^{* * *}$ \\
Charisma (C) & $.37^{* *}$ & $.36^{* * *}$ & $.30^{* * *}$ \\
LMX (L) & $.19^{*}$ & $.32^{* * *}$ & $26 \%$ \\
Follower (F) & $21 \%$ & $21 \%$ & \\
$\mathrm{R}^{2}(\mathrm{C}+\mathrm{L}+\mathrm{F})$ & & $21 \%$ & \\
\hline
\end{tabular}

Dependent variable was the same measure of innovative behavior. Simple correlations, multiple regression betas, and multiple coefficients of determination are shown.

${ }^{*} \mathrm{p} \leq .05$

$* * \mathrm{p} \leq .01$

$* * * p \leq .001$

Support for this assertion is provided by three recent studies (Basu, 1991; Tierney; 1992; Scott, 1993) of leadership within organizations. In these studies, leadership was assessed in terms of multiple domains: the leader (charisma), the follower (follower innovative role expectations; follower's attitude toward innovation), and the dyadic leadership relationship (LMX). Results showed that these three variables in combination generated significant predictable variation in innovative behavior (leadership outcome) beyond any of the three taken alone (see Table 1). In particular, in the three separate studies, charisma demonstrated a suppressor effect on the relationship between LMX and innovative behavior (with charisma entered into the analysis, the relationship between LMX and innovation was much stronger). Thus, if multiple domains had not been considered, the potential leadership contribution would have been underestimated.

In leadership research to date, a plethora of studies have been conducted on the leader, but in comparison there has been a dearth of studies in the other two areas. Clearly, more research is needed on followers and the leadership relationship. By explicitly acknowledging the importance of these other 'components to the leadership process, we hope to encourage more attention to learning as much as we can about all three domains of leadership and how they work together.

We should note at this point that although the insight behind the taxonomy was generated by a levels perspective, the taxonomy actually refers to three domains within the construct of leadership. This is an important distinction because, as will be discussed later in terms of LMX, within each domain (leader, follower, relationship) researchers can adopt different levels of analysis. For example, in the relationship domain, one can examine the relationship from the level of the group, the dyad, the individuals within the dyad, or even larger collectivities. The difference is that the focus of investigation is on the relationship, but the level in which the relationship is analyzed may vary. 
Moreover, we do not claim that this taxonomy is all inclusive. Other domains within the construct of leadership (such as group, team, organization, etc.) have not been included for the sake of simplicity. The taxonomy is intended as a starting point for generation of more comprehensive approaches to leadership study. To provide a clearer understanding of how applying the domains in our taxonomy alters the nature of investigation, we turn next to a brief illustration of the domains in the three component model and how adoption of each perspective affects the type of data generated.

\section{DOMAINS OF LEADERSHIP}

As shown in Table 2, domains of leadership include the leader, the follower, and the relationship. In the leader-based domain, the primary focus is on the leader. The critical issue of interest concerns the question: What is the proper mix of personal characteristics and leader behavior to promote desired outcomes? Based on this viewpoint, studies would include measures that focus on leader behaviors and characteristics, such as leader traits, leader behaviors, personality variables, leader attitudes, leader perceptions, leader power and influence, and so forth. Applying a contingency design, analyses could then examine how the leader-focused variables interact with situational factors to affect outcomes.

Adopting a follower-based perspective, on the other hand, would generate hypotheses and analyses that focus primarily on follower issues. In this case, the critical question of interest would become: What is the proper mix of follower characteristics and follower behavior to promote desired outcomes. 7 Like the leader-based domain, questions raised by this approach would focus on how traits, behaviors, attitudes, perceptions, expectations, and so forth affect the type and effectiveness of certain leadership styles and techniques, but this time with respect to followers. These investigations would thus generate findings concerning followership and its relationship to leadership outcomes.

Finally, a relationship-based approach would focus on the dyadic relationship between the leader and the follower. The critical question of interest in this case would be: What is the proper mix of relational characteristics to promote desired outcomes? Investigation within this domain could focus on identifying characteristics of dyadic relationships (e.g., trust, respect, mutual obligation), evaluating reciprocal influence between leaders and followers, examining how the dyadic relationships are correlated with outcome variables of interest, and researching how effective leadership relationships can be developed, maintained, and combined into collectivities of leadership structures.

As described in the leadership taxonomy, each of these domains should then be considered in combination with the others. This generates a whole new set of questions surrounding the issue of how the characteristics of leader, follower, and relationship interact with each other to influence leadership outcomes. Analysis at this level would have to examine combined and interactive effects of the variables generated by each domain to obtain a more complete picture of the leadership process.

Taken a step further, once the proper mix for each of these domains considered in combination is identified, a subsequent question could address the issue of how these domains may be influenced to enhance the effectiveness of leadership within 
Table 2. Three Domain Approaches to Leadership

\begin{tabular}{|c|c|c|c|}
\hline & Leader-based & Relationship-based & Follower-based \\
\hline What is leadership? & $\begin{array}{l}\text { Appropriate behavior } \\
\text { of the person in leader } \\
\text { role }\end{array}$ & $\begin{array}{l}\text { Trust, respect, and mu- } \\
\text { tual obligation that } \\
\text { generates influence be- } \\
\text { tween parties }\end{array}$ & $\begin{array}{l}\text { Ability and motivation } \\
\text { to manage one's own } \\
\text { performance }\end{array}$ \\
\hline $\begin{array}{l}\text { What behaviors consti- } \\
\text { tute leadership? }\end{array}$ & $\begin{array}{l}\text { Establishing and com- } \\
\text { municating vision; in- } \\
\text { spiring, instilling pride }\end{array}$ & $\begin{array}{l}\text { Building strong rela- } \\
\text { tionships with follow- } \\
\text { ers; mutual learning } \\
\text { and accommodation }\end{array}$ & $\begin{array}{l}\text { Empowering, coaching, } \\
\text { facilitating, giving up } \\
\text { control }\end{array}$ \\
\hline Advantages & $\begin{array}{l}\text { Leader as rallying } \\
\text { point for organization; } \\
\text { common understand- } \\
\text { ing of mission and val- } \\
\text { ues; can initiate whole- } \\
\text { sale change }\end{array}$ & $\begin{array}{l}\text { Accommodates dif- } \\
\text { fering needs of subor- } \\
\text { dinates; can elicit su- } \\
\text { perior work from } \\
\text { different types of } \\
\text { people }\end{array}$ & $\begin{array}{l}\text { Makes the most of fol- } \\
\text { lower capabilities; frees } \\
\text { up leaders for other re- } \\
\text { sponsibilities }\end{array}$ \\
\hline Disadvantages & $\begin{array}{l}\text { Highly dependent on } \\
\text { leader; problems if } \\
\text { leader changes or is } \\
\text { pursuing inappropri- } \\
\text { ate vision }\end{array}$ & $\begin{array}{l}\text { Time-consuming; relies } \\
\text { on long-term relation- } \\
\text { ship between specific } \\
\text { leaders and members }\end{array}$ & $\begin{array}{l}\text { Highly dependent on } \\
\text { follower initiative and } \\
\text { ability }\end{array}$ \\
\hline When appropriate? & $\begin{array}{l}\text { Fundamental change; } \\
\text { charismatic leader in } \\
\text { place; limited diversity } \\
\text { among followers }\end{array}$ & $\begin{array}{l}\text { Continuous improve- } \\
\text { ment teamwork; sub- } \\
\text { stantial diversity and } \\
\text { stability among follow- } \\
\text { ers; Network building }\end{array}$ & $\begin{array}{l}\text { Highly capable and } \\
\text { task committed fol- } \\
\text { lowers }\end{array}$ \\
\hline Where most effective? & $\begin{array}{l}\text { Structured tasks; strong } \\
\text { leader position power; } \\
\text { member acceptance of } \\
\text { leader }\end{array}$ & $\begin{array}{l}\text { Situation favorability } \\
\text { for leader between two } \\
\text { extremes }\end{array}$ & $\begin{array}{l}\text { Unstructured tasks; } \\
\text { weak position power; } \\
\text { member nonacceptance } \\
\text { of leader }\end{array}$ \\
\hline
\end{tabular}

given situations (e.g., how leadership relations can be improved). In particular, as leader (leader-based), follower (follower-based), and relationship (relationship-based) issues become apparent, studies could then focus on how characteristics that are identified may be developed to promote desired outcomes. In contrast to the examples listed above, in this case the direction of causality would be reversed, with leadership becoming the dependent variable. Investigation would take on a prescriptive nature, with studies using experimental designs and longitudinal approaches. Based on this information, training programs focusing on the development of leadership within all of the domains could result.

Thus, the three-component domains of leadership taxonomy reframe our current thinking about leadership study by providing a place for "nontraditional" theories and empirical approaches and by encouraging more multiple-level and domain investigations. The intent of this taxonomy is not to evaluate the worth of an approach or promote further segmentation among theoreticians but rather to stimulate new conceptualizations and empirical approaches within leadership research. As demonstrated by the model, leadership is a multi-faceted construct in- 
volving aspects of the leader, the follower, and the dyadic relationship between the two. Therefore, investigations of leadership should focus on all of these facets. We hope that by using this taxonomy, better integration among theories and broader perspectives of leadership will emerge.

As discussed above, the taxonomy was also developed to provide a better model of fit for leadership theories using nontraditional approaches-theories such as Leader- Member Exchange. Thus, we turn next to a discussion of how LMX fits into the domains of the leadership taxonomy.

\section{LMX as a Relationship-Based Approach to Leadership}

Given the domains of leadership described above, LMX clearly incorporates an operationalization of a relationship-based approach to leadership. The centroid concept of the theory is that effective leadership processes occur when leaders and followers are able to develop mature leadership relationships (partnerships) and thus gain access to the many benefits these relationships bring (Graen \& Uhl-Bien, 1991). The model as it stands describes how effective leadership relationships develop between dyadic "partners" in and between organizations (e.g., leaders and followers, team members and teammates, employees and their competence networks, joint venture partners, suppliers networks, and so forth). This occurs when the relationships generate bases of incremental influence (Katz \& Kahn, 1978) that are necessary for effective leadership. Although LMX has progressed beyond the early dichotomous thinking relative to "in-group" and "outgroup," much of the writing about the theory is still occurring on this level. To bring readers up to date on current thinking about LMX, the development of LMX as a social exchange approach to leadership is described below.

\section{Evolution of LMX from VDL to Leadership Making}

Development of LMX theory may be thought of in terms of four stages (see Figure 2): Stage 1 is the discovery of differentiated dyads; Stage 2 is the investigation of characteristics of LMX relationships and their organizations implications (e.g., outcomes of LMX); Stage 3 is the description of dyadic partnership building; and Stage 4 is the aggregation of differentiated dyadic relationships to group and network levels. This progression has encompassed an evolution in thinking about what LMX has to offer as a leadership model as well as a change in the levels of analysis examined. First, Vertical Dyad Linkage (VDL) research (Dansereau, et al., 1975) documented that leaders do not use an average leadership style but rather develop differentiated relationships with their direct reports (dyads within units). Once the relationship validity was documented, Leader-Member Exchange (LMX) research then investigated the nature of these differentiated relationships and their organizational implications (dyad-level effect). Next, the Leadership Making model (Graen \& Uhl-Bien, 1991; Uhl-Bien \& Graen, 1992, 1993a) recognized the utility of increasing proportions of high-quality relationships in organizations and described a process for accomplishing this through dyadic partnership building (dyad-level effect). Finally, current work is focusing on how these differentiated dyads can be effectively assembled into larger collectivities (collectivities as aggregations of dyads). This evolution represents a pro- 


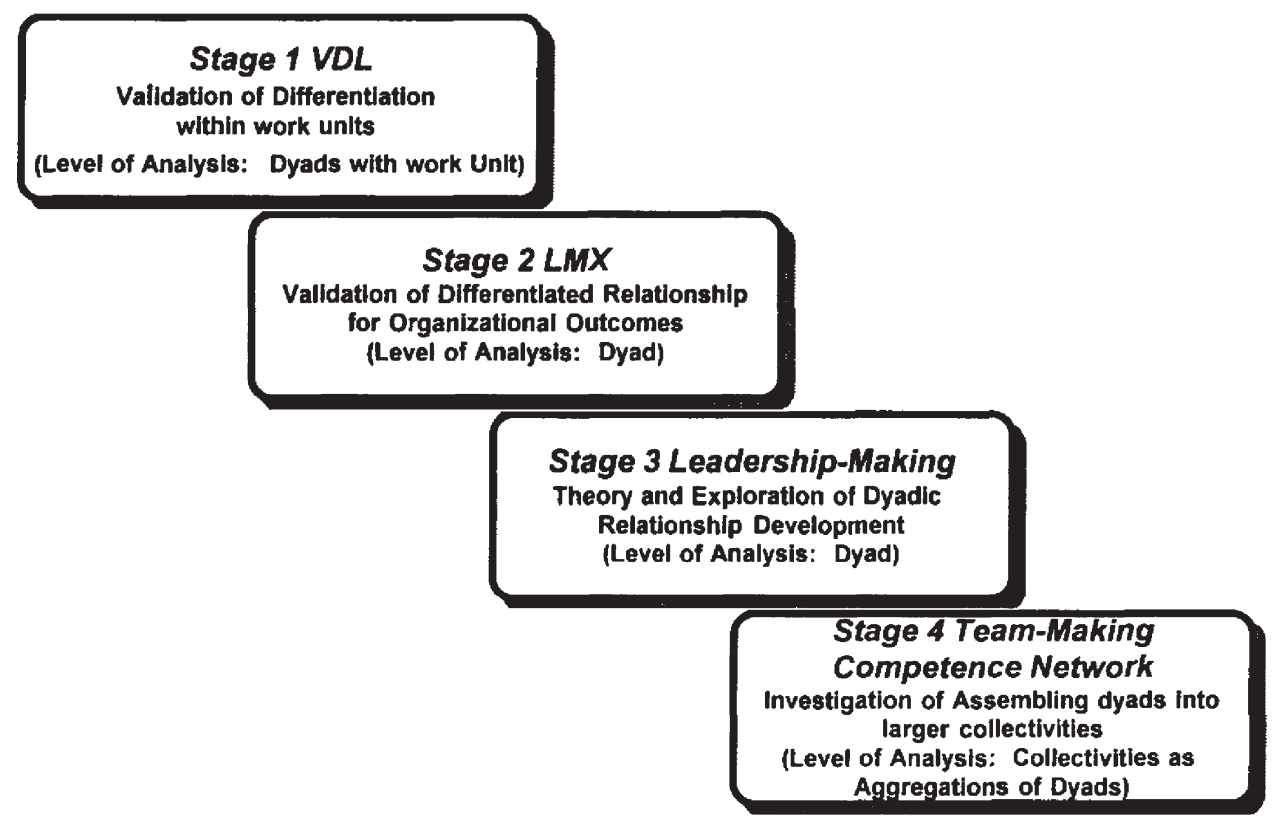

Figure 2. Stages in Development of LMX Theory

cess of learning from the research that has occurred since the early VDL studies. At each stage, the focus of research and the centroid concept has changed slightly. To explain how this progression has evolved, each of the stages are described below.

\section{Stage 1: Discovery of Differentiated Dyads}

Initial investigation into Leader-Member Exchange issues began with studies on work socialization (Graen, Orris, \& Johnson, 1973; Johnson \& Graen, 1973) and Vertical Dyad Linkage (Dansereau et al., 1975; Graen \& Cashman, 1975; Cashman, Dansereau, Graen, \& Haga, 1975; Graen, Cashman, Ginsburgh, \& Schiemann, 1977; Vecchio, 1982; Rosse \& Kraut, 1983). This research discovered that, contrary to prevailing assumptions of the Ohio State and Michigan studies of effective supervision (average leadership style), many managerial processes in organizations were found to occur on a dyadic basis, with managers developing differentiated relationships with professional direct reports. Documentation of the differentiated relationships in the VDL research was obtained in longitudinal studies of management teams by asking managers and their direct reports to describe their work and working relationship in terms of inputs, process, and outcomes. Investigations followed the development of leader-member relationships over time, and studies took place in several different field settings (Graen \& Wakabayashi, 1994).

These early studies did not find support for the average leadership style postulated from the Ohio State and Michigan studies of first-level supervision (Graen, 1976; Graen et al., 1976; Graen \& Schiemann, 1987; Graen, Liden, \& Hoel, 
1982; Graen, Novak, \& Sommerkamp, 1982). Rather, the findings indicated that, when asked to describe the behavior of their manager, different professionals generated very different descriptions of the same person. At one extreme, professionals reported "high-quality exchanges" (at the time called "in-group"), characterized by a high degree of mutual trust, respect, and obligation. At the other extreme, professionals reported "low-quality exchanges" (at the time called "outgroup"), characterized by low trust, respect, and obligation. In high-quality exchange relationships followers acted as "trusted assistants" to the manager and grew beyond their job descriptions. Conversely, in "low-quality exchange" relationships followers acted essentially as "hired hands" who did only what was required by their job descriptions (Zalesny \& Graen, 1987).

The central concept of this early VDL work was that these differentiated relationships resulted from resource constraints on the managers that required them to develop a cadre of trusted assistants to help in the functioning of the work unit. Because these relationships required additional investment of the leader's already limited time and social resources, it was questionable at this point how many high-quality exchanges a leader could profitably develop and maintain. Therefore, expectations were that the managerial units would contain only a few higher-quality exchange relationships, and the remainder of the relationships would be lower-quality exchanges, involving only obligatory compliance by the members with the formal role requirements.

Thus, at this stage, the focus initially was on leader behavior as described by the leader and the follower (leader domain). With the discovery of significant variation in follower responses to questions about their leaders, however, leadermember dyads became the unit for analysis (dyads within units), and the theory began to develop within the relationship domain.

\section{Stage 2: Focus on the Relationship and its Outcomes}

The VDL work was followed by a series of investigations which further validated the existence of these distinctively different relationships within the same units and assessed their implications for organizations. The nomenclature shifted from Vertical Dyad Linkage to Leader-Member Exchange (Graen, Novak, \& Sommerkamp, 1982). The primary thrust was further investigation and testing of the dyadic relationships discovered in Stage 1. To help make sense of this vast body of research, we categorize the work conducted in this stage in terms of two tracts of investigation: (1) studies evaluating characteristics of the LMX relationship, and (2) studies analyzing the relationship between LMX and organizational variables.

Within the first category is a series of conceptual and empirical pieces that delve into the relationship itself. This includes work on dyadic role-making processes (Graen, Orris, \& Johnson, 1973; Graen, 1976; Haga, 1976; Graen, Novak, \& Sommerkamp, 1982; Seers \& Graen, 1984; Snyder \& Bruning, 1985; Zalesny \& Graen, 1987; Graen \& Scandura, 1987; Graen, 1989; McClane, 1991b), investigations of communication frequency (Schiemann \& Graen, 1984; Baker \& Ganster, 1985; Borchgrevink \& Donohue, 1991), investigations of interactive communication patterns relative to LMX (Fairhurst \& Chandler, 1989; Fairhurst, 1993), and leader-member value agreement (Graen \& Schiemann, 1978; Kozlowski \& Doherty, 1989; Ashkanasy \& O'Connor, 1994). In addition, this category includes 
research on antecedents to and/or determinants of LMX (Graen, 1976; Larwood \& Blackmore, 1978; Kim \& Organ, 1982; Duchon, Green, \& Taber, 1986; Steiner, 1988; Heneman, Greenberger, \& Anonyuo, 1989; Liden, Wayne, \& Stilwell, 1993; Vasudevan, 1993), upward maintenance tactics and interaction patterns used by followers in high LMX relationships (Waldron, 1991), subordinate loyalty (Scandura \& Graen, 1984), decision influence (Scandura \& Graen, 1986), influence tactics (Wayne \& Ferris, 1990; Dockery \& Steiner, 1990; Deluga \& Perry, 1991), and member affect about the relationship (Liden, 1985; McClane, 1991a; Day \& Crain, 1992). Moreover, studies investigating characteristics of followers in high LMX relationships identified them as high growth-need strength (Graen et al., 1982; Scandura \& Graen, 1984; Graen, Scandura, \& Graen, 1986), being dependable and having a compatible cognitive decision-making style with the leader (Graen, 1989), being optimistic, appreciative of team skills, internal locus of control, high self-efficacy, long-term planners and strongly career oriented (Vasudevan, 1993), and having perceptions of exerting considerable effort into development of the LMX relationship (Liden \& Mitchell, 1989). Finally, investigations also confirmed and further described the characteristics (mutual trust, respect and obligation) of the differentiated relationship between leaders and followers (Liden \& Graen, 1980; Katerberg \& Horn, 1981; Snyder, Williams, \& Cashman, 1984; Dienesch \& Liden, 1986; Crouch \& Yetton, 1988; Graen, 1989; Fairhurst, 1993), and generalized these findings to the cross-cultural arena (Wakabayashi, Minami, Hashimoto, Sano, Graen, \& Novak, 1980; Wakabayashi \& Graen, 1984; Wakabayashi \& Graen, 1988; Uhl-Bien, Tierney, Graen, \& Wakabayashi, 1990; Wakabayashi, Graen, \& Uhl-Bien, 1990; Eden, 1993).

The second category of investigations in this stage addressed the issue of how these differentiated LMX relationships are related to organizational variables. Studies in this category investigated LMX and performance (Graen et al., 1982; Scandura \& Graen, 1984; Vecchio \& Gobdel, 1984; Castleberry \& Tanner, 1986; Graen, Scandura, \& Graen, 1986; Vecchio, 1987; Weitzel \& Graen, 1989; LaGrace, 1990; Butler \& Reese, 1991; Dunegan, Duchon, \& Uhl-Bien, 1993), turnover (Graen \& Ginsburgh, 1977; Graen, Liden, \& Hoel, 1982; Vecchio \& Gobdel, 1984; Ferris, 1985; Vecchio, Griffeth, \& Horn, 1986), job satisfaction (Graen et al., 1982; Turban, Jones, \& Rozelle, 1990; Stepina, Perrewe, \& Hassell, 1991), organizational commitment (Nystrom, 1990; Seers \& Graen, 1984), performance appraisal (Judge \& Ferris, 1993; Mitchell, 1983; Duarate, Goodson, \& Klich, 1994), job climate (Kozlowski \& Doherty, 1989; Dunegan, Uhl-Bien, \& Duchon, 1992), innovation (Basu, 1991; Tierney, 1992; Scott, 1993), organizational citizenship behavior (Scandura, Graen, \& Novak, 1986; Manogran \& Conlon, 1993; Podsakoff, MacKenzie, \& Hui, 1993; Yammarino \& Dubinsky, 1992), empowerment (Uhl-Bien \& Graen, 1993b; Keller \& Dansereau, 1995; Liden, Wayne, Bradway, \& Murphy, 1994) and procedural and distributive justice (Bell, 1994; Manogran, Stauffer, \& Conlon, 1994; Mansour-Cole, 1994; Scandura, 1994). In addition, longitudinal investigations documented LMX's relationship to career progress (Wakabayashi \& Graen, 1984; Wakabayashi, Graen, Graen, \& Graen, 1988; Graen, 1989; Graen, Wakabayashi, Graen, \& Graen, 1990; Graen \& Wakabayashi, 1993; Bell, 1994), and studies are beginning to test LMX as a moderator (Dunegan, Uhl-Bien, \& Duchon, 1992; Kozlowski \& Doherty, 1989; Kim \& Klein, 1994), within a situational framework (Dunegan, Duchon, \& Uhl-Bien, 
1993) and in terms of relational demography (Tsui \& Egan, 1994; Tsui, Xin, \& Egan, 1994).

Key findings of this stage provided further validation for the existence of differentiated relationships as well as descriptions of the relationships themselves and how they are developed. Findings also documented significant, positive relationships between quality of exchange (LMX) and many outcome variables of interest.

Based on the findings in this stage of investigation, the centroid concept of LMX research may be described as: (1) development of LMX relationships is influenced by characteristics and behaviors of leaders and members and occurs through a role-making process, and (2) higher-quality LMX relationships have very positive outcomes for leaders, followers, work units, and the organization in general. This is different from the VDL approach in that it moves beyond a description of the differentiated relationships in a work unit to an explanation of how these relationships develop and what the consequences of the relationships are for organizational functioning (relationship domain, dyadic level). Thus, based on the findings of this stage, it appears that effective leadership processes occur when leaders and followers develop and maintain high-quality social exchange relationships.

\section{Stage 3: Description of Dyadic Partnership Building}

Based on the implications of the second stage of research (LMX), the more recent work in this area has involved moving beyond "in-groups" and "outgroups" to a focus on generation of more effective leadership process through development of effective leadership relationships (Leadership Making). Using this approach, emphasis is placed not on how managers discriminate among their people but rather on how they may work with each person on a one-on-one basis to develop a partnership with each of them.

The shift in focus moves the theory beyond traditional thinking about "superiors" and "subordinates" to an examination of leadership as a partnership among dyadic members. The key difference in this stage of investigation is that rather than managers treating some employees more favorably than others (as the "differentiation" approach of VDL suggests), this stage states that managers should provide all employees access to the process of LMX by making the initial offer to develop LMX partnerships to each subordinate. Making the partnership offer to every subordinate has a twofold effect: (1) the LMX process may be perceived as more equitable (and the model more palatable to practitioners and students who may have been uncomfortable with the inequity issue) (Scandura, 1995), and (2) the potential for more high-quality relationship development (partnerships) would increase the potential for more effective leadership and expanded organizational capability. Thus, rather than the descriptive approach that comprised the second stage of development, this third stage (Leadership Making) provides a prescriptive, and hopefully a more practically useful, model of leadership development. To elucidate on these issues, the Leadership Making model is described in more detail below.

\section{Leadership Making Model}

The concept of Leadership Making originated with two longitudinal field experiments investigating relationship development among leaders and followers 
(Graen et al., 1982; Scandura \& Graen, 1984; Graen et al., 1986, 1989). In contrast to the VDL assumption that leaders develop high-quality relationships with a select few subordinates, these studies (Graen et al., 1982; Scandura \& Graen, 1984; Graen et al., 1986) analyzed what would happen if leaders were trained to offer the opportunity to develop a high-quality relationship to all of their subordinates. Results showed that those followers who accepted the offer by the leader to develop a high-quality LMX improved their performance dramatically. Moreover, this outcome was consistent for both the initial experimental group and for the initial control group (the initial control group received the treatment in a replicated experimental design after the first experiment was completed). The implications of these findings were that overall unit performance (hard productivity gain) was enhanced by increasing the number of high-quality LMX relationships.

In addition to monitoring both hard and soft outcomes, these studies also examined the process of relationship development by interviewing dyadic members over the duration of the year-long study (dyadic members were interviewed separately before and after each experimental treatment). Analysis of how the relationships unfolded between leaders and members (both where the offer successfully resulted in high-quality relationships and where it did not) provided insight into the process of dyadic partnership building. Thus, based on these studies, the Leadership Making model (Graen \& Uhl-Bien, 1991; Uhl-Bien \& Graen, 1993a) was developed to identify the importance of generating more high-quality relationships within organizations and to describe a process for how these may be realized in practice.

In this model, the process for Leadership Making is described in terms of a life cycle of leadership relationship maturity (Figure 3). The process begins with a "stranger" phase, in which the individuals first come together as strangers occupying interdependent organizational roles. In this phase, interactions between the members occur on a more formal basis-in essence, it can be characterized as a "cash and carry" economic exchange (see characteristics B and C in Figure 3). Within this relationship, exchanges are purely contractual: leaders provide followers only with what they need to perform, and followers behave only as required and do only their prescribed job.

From this phase, an "offer" for an improved working relationship through career-oriented social exchange must be made and accepted (this offer can be made by either party). Once this occurs, the dyads can move to the second stage of relationship development: the "acquaintance" stage. In this stage, increased social exchanges occur between the members, and not all exchanges are contractual. They begin to share greater information and resources, both on a personal and work level. These exchanges are still limited, however, and are part of a testing stage. There is still an equitable return of favors, and these exchanges occur within a limited time period.

When these relationships grow to the next level, they become classified as "mature partnership" exchanges. At this point, exchanges between the members are highly developed: they are exchanges "in kind" and may have a long time span of reciprocation (characteristics B and C in Figure 3). The individuals can count on each other for loyalty and support. Moreover, the exchanges are not only behavioral but also emotional-mutual respect, trust, and obligation grow throughout the process. It is at this stage that the degree of incremental influence and, hence, leadership between the members is extremely high. 

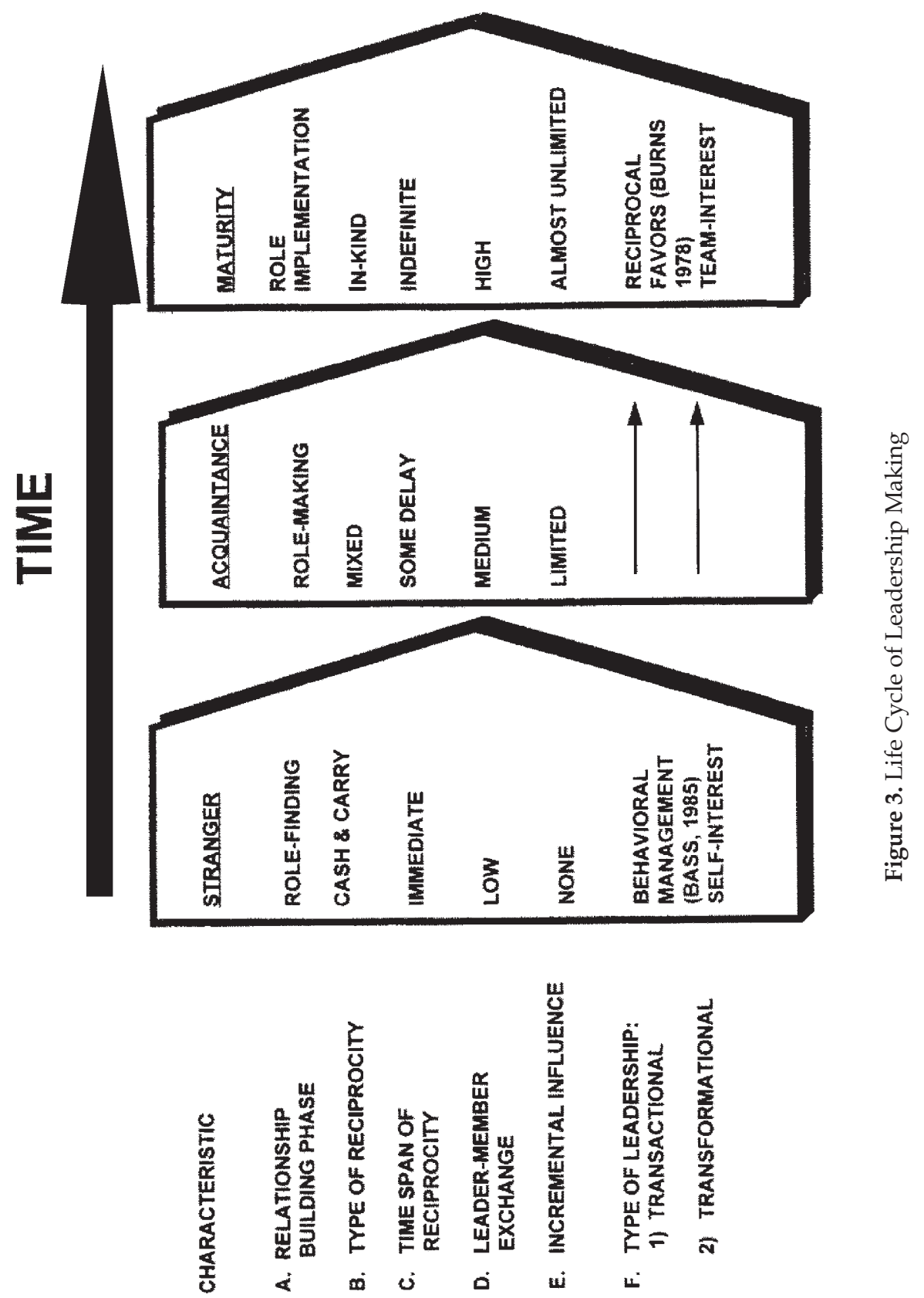
How each dyad progresses through these stages varies in real time. In some dyads, the relationship may not advance much beyond the stranger stage-the leader and member have limited interactions, and those which do occur are strictly contractual. These types of dyads have been documented in the LeaderMember Exchange research (Graen, 1969; Graen, Orris, \& Johnson, 1973; Graen \& Cashman, 1975; Liden \& Graen, 1980; Graen, Novak \& Sommerkamp, 1982; Graen, Scandura, \& Graen, 1986; Graen \& Scandura, 1987; Graen, Wakabayashi, Graen \& Graen, 1990) as lower-quality LMX relationships: those characterized by unidirectional downward influence, economic behavior exchange, formal roledefined relations, and loosely coupled goals (Dansereau, Graen, \& Haga, 1975; Graen, 1976; Graen \& Schiemann, 1978; Vecchio, 1982). In these situations, the leadership process is essentially nonexistent, since incremental influence is not achieved and social exchange is trivial.

This is analogous to the Transactional Leadership model as defined by Bass (1985) (see F(1) in Figure 3) in that the exchange is based upon subordination to the leader. In this case, the leader makes requests based upon his/her hierarchical status within the organization, and the follower complies because of his/her formal obligation to the leader and because of the economic rewards the leader controls. Similarly, the motivations of the follower are based upon the satisfaction of his/ her own self-interests, without consideration of the good of the group (characteristic F(2) in Figure 3). Rather than social exchange of favors, this conception of transactional leadership is based more upon the fundamental ideas of managership and behavior modification (Skinner, 1953).

In other dyads, leaders and followers may advance beyond the "stranger" stage into the "acquaintance" stage. In these cases (intermediate LMX quality dyads), leaders and members may develop a somewhat more involved relationship, however, the incremental influence (characteristic E in Figure 3) is still limited. Leadership processes in these dyads are more effective than in the stranger stage, but the high degree of mutual respect, trust, and obligation necessary for truly effective leadership still has not been fully developed. This acquaintance stage is a critical stage in the leadership development process since those dyads who do not develop to the mature stage eventually fall back to the first stage.

For those dyadic members who make it to the mature "partnership" stage, the payoffs can be tremendous. In partnership relationships, the potential for incremental influence is nearly unlimited, due to the enormous breadth and depth of exchange of work-related social contributions that are possible (Burns, 1978). At this stage, the mature relationship developed between the dyadic members throughout the history of the exchange results in progressively higher degrees of mutual trust, respect, and obligation within the relationship (Characteristic $F(1)$ in Figure 3), persuading followers to engage in more responsible activities than they otherwise would. Leaders can count on the followers to provide them with partnership assistance when needed. For example, they may rely on a follower to take on extra position assignments without pay and/or provide honest, constructive criticism where others may feel intimidated. Likewise, followers may rely on the leaders for needed support, encouragement, and career investments. It is this mutual trust, respect, and obligation toward each other which empowers and motivates both to expand beyond the formalized work contract and formalized work roles: to grow out of their prescribed jobs and develop a partnership based on mutual reciprocal influence (characteristic F(2) in Figure 3). 
This "transformation"(Burns, 1978) to "partnerships" is accompanied by a movement among members beyond their own self-interests to focus more on larger mutual interests. Dyadic members recognize that by satisfying "partnership" interests they are also able to fulfill their own interests and more. When this occurs, formalized hierarchical relationships are no longer emphasized by the partners and the relationship becomes one more like peers than superior-subordinate. Moreover, because of their special relationship, the partners have the resources and support that allow them to take on additional responsibilities within the organization.

Effective leadership making - that which produces mature leadership relationships - thus results in more effective leadership outcomes (Uhl-Bien \& Graen, 1993a): dyadic partners are able to exert considerable incremental influence with each other, and each member gains greater access to resources and support from the other than he or she would have otherwise. Partners in these relationships experience reciprocal influence (the leadership role can rotate between partners), mutual trust, respect, and obligation and internalization of common goals (Duchon, Green, \& Taber, 1986; Fairhurst, Rogers, \& Sarr, 1987; Crouch \& Yetton, 1987; Fairhurst \& Chandler, 1989; Fairhurst, 1993). In addition, followers are willing to exert extra effort by engaging in activities that are not specifically prescribed by the organization, such as taking personal initiative, exercising personal leadership to make their work unit more effective, taking career risks to accomplish assignments, being good organization citizens, and so forth (Graen, 1989).

Thus, Stage 3 comprises an intense focus on the dyad by addressing issues of how high-quality relationships develop without reference to any particular organizational unit (relationship domain, dyadic level). This stage moves us out of the "in-group/ outgroup" thinking of Stage 1 to a more practical and more equitable model for building leadership throughout the organization. The thrust of this stage is that since these relationships are beneficial for dyadic members and organizations, managers should be encouraged (and trained) to make the offer of high-quality relationship (partnership) building to all of their subordinates. Whether all of these offers will result in high-quality relationship development is problematic (and unlikely), but as long as the offers are made, the LMX process may be perceived as more equitable, and the potential for more high-quality relationships (and hence more effective leadership) will be increased. Obviously, many of these issues are in need of further testing, but this stage begins to raise questions that we believe will lead to more effective leadership in organizations.

\section{Stage 4: Expansion of Dyadic Partnership to Group and Network levels}

Up to this point, most of the work on LMX has focused on LMX relationships as dyads within work groups and independent dyads. Within complex organizations, however, this is not representative of the nature of leadership situations, which are characterized most often by a leader and multiple members working together in some type of interacting collectivity. In recognition of this, Graen and Scandura (1987) proposed that, rather than independent dyads, LMX should be viewed as systems of interdependent dyadic relationships, or network assemblies (Scandura, 1995). To address this issue, Stage 4 adopts a systemslevel perspective and pursues the question of how differentiated dyadic relationships combine together to form larger systems of network assemblies (Uhl-Bien \& Graen, 1992, 1993a, 1993b). 
These network assemblies constitute the leadership structure within the organization. Compatible with Katz and Kahn's (1978) conceptualization of role sets, we define leadership structure as the pattern of leadership relationships among individuals throughout the organization. This structure includes but is not limited to the work unit. Rather, the relationships that make up the leadership structure cut across work unit, functional, divisional, and even organizational boundaries. Moreover, these relationships are not limited to formal superior-subordinate relationships but include leadership relationships among peers, teammates, and across organizational levels and organizations.

The leadership structure is not formally designed; it emerges from the enactment of formally defined roles by organizational members. In order to carry out these roles and complete tasks, organizational members develop a network of relationships based on mutual dependencies. How these relationships develop varies within and across organizations, and depends upon task structure and individual characteristics of organizational members. The same formal roles may be enacted very differently by different individuals and/or combinations of individuals within the organization (Weick, 1969; Hackman, 1986). The enactment, however, is what most accurately reflects how work really gets completed within organizations. In order to understand organizational and leadership effectiveness, therefore, we must generate a better understanding of this leadership structure.

Stage 4 attempts to do this by "mapping" the leadership structure on the task structure of the organization. Investigation at this level looks at task interdependencies and the quality of the relationships that develop among organizational participants as a result of these interdependencies. More effective leadership relationships among organizational participants would obviously facilitate completion of task requirements. However, some relationships will likely be more critical in influencing the success/failure of work activities than others. Moreover, relationship quality in some parts of the leadership structure will likely influence relationship development and relationship effectiveness in other parts of the structure. Therefore, Stage 4 involves investigating patterns of relationship quality within the leadership structure, taking into consideration the criticality of relationships for task performance, as well as the effects of differentiated relationships on each other and on the entire structure.

Research at this stage would address issues at several levels. At the workgroup level, the predominant issues would involve the question of how higherquality and lower-quality exchanges are aggregated within a single work unit and what their combined effect is on group-level work processes and outcomes. More specific questions include: how do members of higher-quality exchanges and lower-quality exchanges within the same work group get along? How do differentiated exchanges within the same work group affect task performance? How do they affect attitudes of work-group members (Forret \& Turban, 1994)? How many high-quality relationships can be supported within a single work group? Is there one "best" combination/proportion of LMXs within work groups (e.g., some combination of highs and lows, all highs, etc.)? Does this vary with varying task roles and requirements? Why is it that differentiation occurs-is it because the manager does not make the offer to all subordinates or because some subordinates reject the offer? Is it valid to believe (as we do) that the relationship that 
transpires between a superior and his/ her subordinate is independent of those relationships formed with other subordinates (as found by Keller \& Dansereau, 1995)? How do equity issues influence perceptions of relationships among workunit members (Scandura, 1995)? How does a change in group membership affect the balance of LMXs within a work group? How do peer influences affect a work-group member's relationship development with the leader? And, how do members with differentiated exchanges actually work together (e.g., what kinds of roles do they play)?

Expanding beyond the immediate work group, similar questions emerge about relationship development across work groups and throughout the organization: Does the quality of relationships an individual develops with his/ her formal leader and immediate co-workers affect the kinds of relationships they develop in other parts of the organization? Does the quality of these relationships affect individuals' performance in activities that expand beyond their work unit (e.g., cross-functional work teams) and in what way (e.g., access to resources, inside information, etc.)? What are the critical task networks and what kinds of relationships are necessary for effective enactment of these networks? What happens when changes occur in membership within the network? And, what can be done to make leadership structures more effective for task completion?

Finally, crossing organizational boundaries, questions include: How does the pattern of relationships affect an employee's interactions with customers, suppliers, and other organizational stakeholders? Are individuals who are effectively positioned within the organizational structure (e.g., who have high-quality relationships with critical others) more effective in external relationships, in what way, and how does this affect organizational performance? Finally, what combination of relationships is most positive or most detrimental to cross-organizational interactions?

Obviously, these are only some of the questions that could be considered, and other critical issues may have been missed. This discussion begins to reveal, however, the vast potential and rich opportunities for generating valuable insight into organizational functioning by rethinking traditional conceptualizations of leadership and expanding LMX out of its narrow focus to a broader, multi-level, multidomain framework.

To date, we are not aware of any empirical investigations of leadership at this level. This is because, in contrast to the earlier stages, Stage 4 is in its infancy. Very little empirical investigation has occurred at this level, and questions abound. Given the import of understanding the processes identified in this stage for practitioners and researchers alike, however, further investigation and theorizing at this stage should be more vigorously pursued.

Thus, as described at the beginning of this discussion, we can clearly see that LMX theorizing and research has undergone an evolution. Each stage represents a shift in focus and a progression in thinking about the LMX process within organizations. Although we have attempted to clarify our thinking about LMX, however, questions raised about LMX by others in the field still remain. Therefore, we turn next to a discussion of our response to questions and concerns regarding the issues of the measurement and dimensionality of the LMX construct and how LMX compares to transactional and transformational approaches. 


\section{Measurement and Dimensionality of the LMX Construct}

Healthy controversy currently surrounds the question of the measurement and the dimensionality of the LMX construct. This controversy emanates from two primary sources: (1) the continual redefining of the LMX scale in studies over the years, as well as the use of measures altogether different from the original formulation of the measure (Kim \& Organ, 1982; Rosse \& Kraut, 1983; Heneman, Greenberger, \& Anonyuo, 1990 as cited in Keller \& Dansereau, 1995), and (2) questions about whether LMX is unidimensional or multidimensional and what the implications of this are for measurement.

In response to the first question, we acknowledge that the measure of LMX has changed over the years. Investigations have used the 2-item (Dansereau, et al., 1975), 4-item (Graen \& Schiemann, 1978; Liden \& Graen, 1980), 5-item (Graen, Liden, \& Hoel, 1982), 7-item (Graen, Novak, \& Sommerkamp, 1982; Seers \& Graen, 1984), 10-item (Ridolphi \& Seers, 1984), 12-item (Wakabayashi \& Graen, 1984), and 16-item (Wakabayashi, Graen, \& Uhl-Bien, 1990; Uhl-Bien et al., 1990) LMX scale. This refinement of the measure has occurred from our learning through research and theorizing about LMX. Different measures have involved the use of added experimental items to tap into and test the dimensionality of LMX. Conclusion from this testing indicates to us that, even though items were added to tap into possible multiple dimensions, the expanded measure was highly correlated with the more concise 7-item LMX and produced the same effects. Moreover, although multiple factors were generated for the larger measures, the Cronbach alphas for the single measure were consistently in the $80 \%-90 \%$ range, and the high correlations among the factor scales made consideration of these factors as multiple measures inappropriate (Cashman, 1975; Schiemann, 1977; Seers, 1981; Schriesheim \& Gardner, 1992; Scott, 1993; Bell, 1994). Therefore, we conclude that the 7-item LMX, with the centroid item of "How effective is your working relationship with your leader?" is the most appropriate and recommended measure of LMX. Of course, we shall continue to develop psychometrically new and improved versions of LMX.

In terms of the use of alternate measures of LMX, we can only postulate that this was due to lack of accessibility of the LMX measure. To alleviate this potentiality, we provide a version of the recommended measure of LMX-7 in Table 3.

The second area of controversy concerns the dimensionality of LMX. Dienesch and Liden (1986, p. 624) were the first to raise this issue with their question about whether LMX is unidimensional or multidimensional. In response to this question, Dienesch and Liden took the position that LMX is multidimensional, and identified the dimensions as perceived contribution, loyalty, and affect. Following their lead, others have begun to conduct their own testing on the dimensionality of LMX and to develop other LMX measures (Dienesch, 1985; Schriesheim, Neider, Scandura, \& Tepper, 1992; Phillips, Duran, \& Howell, 1993; Liden, 1993; Liden \& Maslyn, 1994). The most consistent finding of the testing across these studies, however, is homogeneity on the single dimension (Cronbach alphas for single measure in the $80 \%-90 \%$ range) and mixed findings for multidimensionality (most of the studies did not find multiple factors in exploratory factor analyses but did find multiple dimensions when factors were forced in confirmatory factor analyses) (Joreskog \& Sorbom, 1989). Given these findings and our own testing of 
Table 3. Recommended Measure of LMX (LMX 7)

1. Do you know where you stand with your leader . . do you usually know how satisfied your leader is with what you do? (Does your member usually know)

Rarely Occasionally Sometimes Fairly Often Very Often

2. How well does your leader understand your job problems and needs? (How well do you understand)
Not a Bit
A Little
A Fair Amount
Quite a Bit
A Great Deal

3. How well does your leader recognize your potential? (How well do you recognize)
Not at All
A Little
Moderately
Mostly
Fully

4. Regardless of how much formal authority he/she has built into his/her position, what are the chances that your leader would use his/her power to help you solve problems in your work? (What are the changes that you would)

None Small Moderate High Very High

5. Again, regardless of the amount of formal authority your leader has, what are the chances that he/she would "bail you out," at his/her expense? (What are the chances that you would)

None Small Moderate High Very High

6. I have enough confidence in my leader that I would defend and justify his/her decision if he/she were not present to do so? (Your member would)

Strongly Disagree Disagree Neutral Agree Strongly Agree

7. How would you characterize your working relationship with your leader? (Your member)

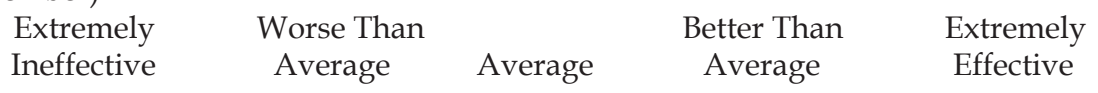

Continuous scale of sum of 5-point items (1 left to 5 right). Leader's form consists of same seven items asked about member of (leader in parentheses). Expected agreement between leader and member reports is positive and strong and used as index of quality of data.

the dimensionality of the LMX construct (discussed above), we conclude that the LMX construct has multiple dimensions, but these dimensions are so highly correlated they can be tapped into with the single measure of LMX. We suggest that the massive redundancy resulting from using more than one measure of LMX at this time can add little unique information.

In terms of our position on dimensionality, we theorize that LMX contains three dimensions - namely respect, trust, and obligation. Furthermore, we postulate that the offer to another to build a partnership LMX is based upon these three factors. An offer will not be made and accepted without (I) mutual respect for the capabilities of the other, (2) the anticipation of deepening reciprocal trust with the other, and (3) the expectation that interacting obligation will grow over time as career-oriented social exchanges blossom into a partnership. Development of LMX is based on the characteristics of the working relationship as opposed to a personal or friendship relationship, and this trust, respect, and mutual obligation 
refer specifically to the individuals' assessments of each other in terms of their professional capabilities and behaviors. This is different from the liking-based dimensions of interpersonal attraction and bonding suggested by others (e.g., Liden \& Maslyn, 1994). Moreover, these dimensions differ from antecedents to LMX (as being developed in our LMX Readiness scale; Vasudevan, 1993) and describe the stages of relationship development from the initial interactions to mature relationships (initial stage involves respect and then trust, and mutual obligation follows). (Note that antecedents are different in that they address trait-like factors such as an individual's readiness to accept obligation, trust in other people, individual's evaluation of the value of a partnership, and so forth).

\section{Is LMX Transformational or Transactional?}

Bass' (1990) development of the Transactional/Transformational Leadership model (based on Burns, 1978) has contributed to some ambiguity in how LeaderMember Exchange theory should be classified in terms of these approaches. The biggest problem we have seen emerge from this controversy is the classification of LMX as Transactional Leadership. Although we agree that some aspects of LMX are transactional due to its position as an exchange-based approach to leadership, LMX is clearly not limited to Transactional Leadership. Rather, LMX is both transactional and transformational: it begins as transactional social exchange and evolves into transformational social exchange.

Much of the ambiguity is likely due to confusion about what is meant by transactions, or exchanges. Transactional leadership as described by Bass (1990) refers primarily to material exchange-for example, material compensation that is exchanged for fulfillment of the employment contract. Exchange is not limited to material transactions, however; it may also involve social exchange or exchanges of psychological benefits or favors (e.g., approval, trust, esteem, support, consideration). This social exchange is what comprises the Leader-Member Exchange process. (Note that while some consider social exchanges to include material exchange [e.g., Yukl, 1989, p. 271, we describe it as the psychological or social aspects of exchange).

When consideration is given to the distinction between material and social exchange in terms of transactional and transformational approaches, one can more clearly see how LMX can be both of these processes. As discussed in the Leadership-Making model, development of LMX relationships begins with individuals who are strangers and engage in initial testing behaviors (limited social exchanges). This "testing process" through "social transactions" results in some relationships which advance to the acquaintance stage, with a greater amount of social exchange. Of these dyads, some are able to advance even further to "partnerships." According to the model, these partnership relationships experience a "transformation" from self-interest to a larger interest. Thus, the type of leadership that occurs in the stranger and acquaintance dyads (low to medium LMX) aligns more closely with descriptions of transactional leadership, and the dyads that are able to "transform" into partnership dyads (high LMX) align more closely with transformational leadership.

Material exchange is different from social exchange (and LMX), in that when material exchange is the basis for the relationship, the process is not really leadership; it is closer to "managership" or "supervision." In these situations, the em- 
ployment contract is the basis for behaviors by both the leader and follower. The contract is fulfilled at the most basic level (Transactional Leadership) by testing various contingencies of behavior and reciprocal compensation. This would involve no leadership at all, and minimal amounts of managership. More advanced dyads (Transformational Leadership) are those in which managers perform very effectively in terms of their formal roles. In these situations, managers most effectively use all the contingencies in the system with subordinates, thereby creating a long-term commitment from followers to the organization.

Thus, LMX is both transactional and transformational. It is a dyadic social exchange process that begins with more limited social "transactions" (e.g., transactional leadership), but for those who are able to generate the most effective LMX relationships, the type of leadership that results is transformational.

\section{Suggestions for Future Research}

Although many ideas for future research have been raised throughout the article, we would like to summarize our thoughts about directions for leadership research, in general, and Leader-Member Exchange, in particular. In terms of leadership research in general, the three-domain taxonomy of leadership approaches clearly states that more multi-domain studies need to be conducted on leadership. These studies need to look more closely at the neglected areas of followership and leadership relationships, as well as examining how the follower and relationship domains interact with more traditional leader-based approaches to affect leadership outcomes. Work in this area should be both descriptive and prescriptive (see "Domains of Leadership" section for more detailed discussion). Moreover, studies should adopt different levels of analysis within each domain.

In terms of Leader-Member Exchange, the greatest amount of future research attention is needed at Stages 3 and 4. The Leadership Making model (presented in Stage 3) needs to be further tested through empirical documentation of the manner in which leadership relationships develop. Liden and colleagues (Liden, Wayne, \& Stilwell, 1993), Bauer and Green (1994), and Uhl-Bien and Graen (1993b) have conducted some testing in this area, but many more opportunities exist to explore the relationship development process. For example, a study could take a "life-cycle" approach and break relationship development into stages (e.g., initial exchanges, early development, maturity, and decline). Other investigations could pursue the roles each member plays in the relationship development process. Still others could investigate what could be done to ensure more effective relationship development among dyadic members.

Similarly, Stage 4 provides endless opportunities for investigation and theoretical development. This stage opens a vast new domain to leadership research with its acknowledgment of the leadership structure and the importance of understanding how it operates within organizations. More specifically, the dyadic approach to group and network analysis (e.g., groups and networks as combinations of dyads) presented in Stage 4 recommends that studies consider the dyadic makeup of the leadership structure throughout the organization. This is meant to say not that groups and networks are only the sum of their dyadic components (we believe there is also a synergistic effect) but that consideration of dyadic relationships as the building blocks of these larger collectivities provides greater op- 
portunities for understanding and enhancing leadership processes within these collectivities. Thus, investigations are needed to assess members' perceptions of the relationship between their own and others' dyadic relationships as well as how the patterns of relationships affect leadership and organizational outcomes (numerous specific research questions for this stage were also addressed in the earlier section on Stage 4).

Finally, although a plethora of studies have been conducted at Stage 2, it is valuable to further identify characteristics of differentiated LMX relationships as well as to continue testing the relationship between LMX and organizational outcome variables of interest. Some additional issues to consider at this stage are situational aspects of LMX (e.g., Dunegan, Duchon, \& Uhl-Bien, 1992; Dunegan, Uhl-Bien, \& Duchon, 1992) and LMX as a moderator variable, and studies should be conducted at different levels of analysis (e.g., measure from leader's perspective, member's perspective, and so forth).

\section{Conclusion}

The article has attempted to clarify thinking about Leader-Member Exchange and stimulate new thought about where the theory is headed. The article also attempted to identify problems in traditional conceptualizations about leadership and promote consideration of leadership within a broader framework. We believe the article provides several significant contributions to the current literature. Specifically, the present article: (1) presents a taxonomy of leadership approaches based on a multi-level multi-domain perspective to promote a more comprehensive approach to leadership study and provide a new classification system that is responsive to "nontraditional" leadership theories; (2) adopts a levels perspective to identify the stages of development of Leader-Member Exchange theory, and summarizes the LMX literature within these stages; (3) describes the development of LMX from the "in-group/out-group" model to a more prescriptive and practically useful model; (4) clarifies issues of measurement and dimensionality of LMX as well as where LMX fits into Transactional and Transformational Leadership approaches; and (5) provides directions for future research in LMX and leadership.

Many have been arguing for more consideration of multi-level issues within organizational research, and the present article is a product of such consideration. Theorizing and research on LMX has occurred over the years on multiple levels; yet, to date, consideration of LMX theory and research from this perspective has not been documented. By adopting this perspective, we have come to a clearer understanding of leadership and LMX, and agree with Klein et al. (1994) and Dansereau et al. (1984) that, at least in our case, greater attention to levels issues has increased the clarity, testability, comprehensiveness, and creativity of our organizational theorizing. We hope that the result of our "levels" exercise will promote more comprehensive investigations into leadership and LMX and that by following the suggestions provided in this article, leadership can become the concept that integrates micro and macro organizational behavior.

Acknowledgments: The senior author would like to acknowledge the intellectual excitement, delightful partnership, and social obligation contributed by three generations of LMX researchers and to thank Marvin Dunnette for making it all possible. Both authors 
wish to thank Joan Graen for processing the manuscript, Pamela Brandes-Duncan for her research assistance, and Fred Dansereau and three anonymous reviewers for their helpful comments and insights.

\section{References}

Ashkanasy, N.M., \& O'Connor, C. (1994). Value differences as a barrier in leader-member exchange: A multidimensional scaling analysis. Paper presented at the Academy of Management annual meeting, Dallas, TX.

Baker, D.D., \& Ganster, D.C. (1985). Leader communication style: A test of average versus vertical dyad linkage models. Group \& Organization Studies, 10, 242-259.

Bass, B.M. (1985). Leadership and Performance beyond Expectations. New York: The Free Press.

Bass, B.M. (1990). Bass \& Stogdill's Handbook of Leadership. New York: Free Press.

Basu, R. (1991). An empirical examination of leader-member exchange and transformational leadership as predictors of innovation behavior. Unpublished Ph.D. dissertation, Department of Management, Purdue University.

Bauer, T.N., \& Green, S.G. (1994). Leader-member exchange: Relationships with performance expectations and leader delegation at two points in time. Paper presented at the Academy of Management Meetings, Dallas, TX.

Bell, L.M. (1994). Looking for passages through the glass ceiling: An empirical field investigation into the effects of gender, age and leader-member exchange relationships on the career progress and career perceptions of working professionals. Unpublished Ph.D. dissertation, Department of Management, University of Cincinnati.

Borchgrevink, C.P., \& Donohue, W.A. (1991). Leader-member exchange and psychological distance: An investigation of verbal immediacy in the exchange. Unpublished manuscript, Michigan State University.

Burns, J.M. (1978). Leadership. New York: Harper \& Row.

Butler Jr., J.K., \& Reese, R.M. (1991). Leadership style and sales performance: A test of the situational leadership model. Journal of Personal Selling \& Sales Management, 11, 37- 46.

Cashman, J. (1975). Empirical test of role-making model of leadership in formal organizations: A developmental approach. Unpublished Ph.D. dissertation (S. Rains Wallace Award finalist), Department of Management, University of Illinois.

Cashman, J., Dansereau, F., Jr., Graen, G.B., \& Haga, W.J. (1976). Organizational understructure and leadership: A longitudinal investigation of role-making process. Organizational Behavior and Human Decision Processes, 15, 278-296.

Castleberry, S.B., \& Tanner, J.F., Jr., (1986). The manager-salesperson relationship: An exploratory examination of the vertical-dyad linkage model. Journal of Personal Selling $\mathcal{E}$ Sales Management, 6, 29-37.

Crouch, A., \& Yetton, P. (1988). Manager-subordinate dyads: Relationships among task and social contact, manager friendliness, and subordinate performance in management groups. Organizational Behavior and Human Decision Processes, 41,65-82.

Dansereau, F., Alutto, J.A., \& Yammarino, F.J. (1984). Theory Testing in Organizational Behavior: The Variant Approach. Englewood Cliffs, NJ: Prentice-Hall.

Dansereau, F., Graen, G.B., \& Haga, W. (1975). A vertical dyad linkage approach to leadership in formal organizations. Organizational Behavior and Human Performance, 13, 46-78.

Day, D.V., \& Cram, E.C. (1992). The role of affect and ability in initial exchange quality perceptions. Group \& Organization Management, 17, 380-397. 
Deluga, R.J., \& Perry, J.T. (1991). The relationship of subordinate upward influencing behavior, satisfaction and perceived superior effectiveness with Leader-Member Exchanges, Journal of Occupational Psychology, 64, 239-252.

Dienesch, R.M. (1985). A three dimensional model of leader-member exchange: An empirical test. Paper presented at the Academy of Management annual meeting, San Diego, CA.

Dienesch, R.M., \& Liden, R.C. (1986). Leader-member exchange model of leadership: A critique and further development. Academy of Management Review, 11, 618-634.

Dockery, T.M., \& Steiner, D.D., (1990). The role of the initial interaction in leader-member exchange. Group and Organization Studies, 15, 395-413.

Duarate, N.T., Goodson, J.R., \& Klich, N.R. (1994). Effects of dyadic quality and duration on performance appraisal. Academy of Management Journal, 37, 499-521.

Duchon, D., Green, S., \& Taber, T. (1986). Vertical dyad linkage: A longitudinal assessment of antecedents, measures, and consequences. Journal of Applied Psychology, 71, 56-60.

Dunegan, K.J., Duchon, D., \& Uhl-Bien, M. (1992). Examining the link between leadermember exchange and the subordinate performance: The role of task analyzability and variety as moderators. Journal of Management, 18, 59-76.

Dunegan, K.J., Uhl-Bien, M., \& Duchon, D. (1992). Task-level climate and LMX as interactive predictors of performance. Paper presented at the Academy of Management annual meeting, Las Vegas, Nevada.

Eden, D. (1993). Leadership and expectations: Pygmalion effects and self-fulfilling prophecies in organizations. Leadership Quarterly, 3, 271-305.

Fairhurst, G.T. (1993). The leader-member exchange patterns of women leaders in industry: A discourse analysis. Communication Monograph, 60, 321-351.

Fairhurst, G.T., \& Chandler, T.A. (1989). Social structure in leader-member exchange interaction. Communication Monograph, 56, 215-239.

Fairhurst, G.T., Rogers, L.E., \& Sarr, R.A. (1987). Manager-subordinate control patterns and judgments about the relationship. In: M. McLaughlin (Ed.), Communications Yearbook (Vol. 10, pp. 395-415). Beverly Hills, CA: Sage.

Ferris, G.R. (1985). Role of leadership in the employee withdrawal process: A constructive replication. Journal of Applied Psychology, 70, 777-781.

Forret, M.L., \&Turban, D. (1994). The leader-member exchange model: A review and directions for future research. Paper presented at the Academy of Management annual meeting, Dallas, TX.

Graen, G.B. (1969). Instrumentality theory of work motivation: Some experimental results and suggested modifications. Journal of Applied Psychology, 53 (whole no. 2, part 2).

Graen, G.B. (1976). Role making processes within complex organizations. In: M.D. Dunnette (Ed.), Handbook of Industrial and Organizational Psychology (pp. 1201-1245). Chicago: Rand-McNally.

Graen, G.B. (1989). Unwritten Rules for Your Career: 15 Secrets for Fast-Track Success. New York: John Wiley \& Sons.

Graen, G.B., \& Cashman, J. (1975). A role-making model of leadership in formal organizations: A developmental approach, In: J.G. Hunt \& L.L. Larson (Eds.), Leadership Frontiers (pp. 143-166). Kent, OH: Kent State University Press.

Graen, G.B., Cashman, J., Ginsburgh, S., \& Schiemann, W. (1977). Effects of linking-pin quality upon the quality of working life of lower participants: A longitudinal investigation of the managerial understructure. Administrative Science Quarterly, 22, 491-504. 
Graen, G.B., \& Ginsburgh, S. (1977). Job resignation as a function of role orientation and leader acceptance: A longitudinal investigation of organizational assimilation. Organizational Behavior and Human Performance, 19, 1-17.

Graen, G.B., Liden, R., \& Hoel, W. (1982). Role of leadership in the employee withdrawal process. Journal of Applied Psychology, 67, 868-872.

Graen, G.B., Novak, M., \& Sommerkamp, P. (1982). The effects of leader-member exchange and job design on productivity and satisfaction: Testing a dual attachment model. Organizational Behavior and Human Performance, 30, 109-131.

Graen, G.B., Orris, D., \& Johnson, T. (1973). Role assimilation processes in a complex organization. Journal of Vocational Behavior, 3, 395-420.

Graen, G.B., \& Scandura, T. (1987). Toward a psychology of dyadic organizing. In: B. Staw \& L.L. Cumming (Eds.), Research in Organizational Behavior (Vol. 9, pp. 175-208). Greenwich, CT: JAI Press.

Graen, G.B., Scandura, T.A., \& Graen, M.R. (1986). A field experimental test of the moderating effects of growth need strength on productivity. Journal of Applied Psychology, 71, 484-491.

Graen, G.B., \& Schiemann, W. (1978). Leader-member agreement: A vertical dyad linkage approach. Journal of Applied Psychology, 63, 206-212.

Graen, G.B., \& Uhl-Bien, M. (1991a). The transformation of professionals into self-managing and partially self-designing contributions: Toward a theory of leader-making. Journal of Management Systems, 3(3), 33-48.

Graen, G.B., \& Uhl-Bien, M. (1991b). Partnership-making applies equally well to teammate-sponsor teammate-competence network, and teammate-teammate relationships. Journal of Management Systems, 3(3), 49-54.

Graen, G.B., \& Wakabayashi, M. (1994). Cross-cultural leadership-making: Bridging American and Japanese diversity for team advantage. In: H.C. Triandis, M.D. Dunnette, \& L.M. Hough (Eds.), Handbook of Industrial and Organizational Psychology (Vol. 4, pp. 415446). New York: Consulting Psychologist Press.

Graen, G.B., Wakabayashi, M., Graen, M.R., \& Graen, M.G. (1990). International generalizability of American hypothesis about Japanese management progress: A strong inference investigation. The Leadership Quarterly, 1, 1-23.

Hackman, J.R. (1986). The design of work teams. In: J. Lorsch (Ed.), Handbook of Organizational Behavior (pp. 315-412). Englewood Cliffs, NJ: Prentice-Hall.

Haga, W.J. (1976). Managerial professionalism and the use of organization resources. American Journal of Economics and Sociology, 35, 337-348

Heneman, R.L., Greenberger, D.B., \& Anonyuo, C. (1989). Attributions and Exchanges: The effects of interpersonal factors on the diagnosis of employee performance. Academy of Management Journal, 32, 466-476.

Hollander, E.P. (1978). Leadership Dynamics: A Practical Guide to Effective Relationship. New York: Free Press.

Joreskog, K.G., \& Sorbom, D. (1989). Lisrel 7. A Guide to Program and Applications Chicago: SPSS, Inc.

Johnson, T., \& Graen, G.B. (1973). Organizational assimilation and role rejection. Organizational Behavior and Human Performance, 10, 72-78.

Judge, T.A., \& Ferris, G.R. (1993). Social context of performance evaluation decisions. Academy of Management Journal, 36, 80-105.

Katerberg, R., 62 Horn, P.W. (1981). Effects of within-group and between groups variation in leadership. Journal of Applied Psychology, 66, 218-223. 
Katz, D., \& Kahn, R.L. (1978). The Social Psychology of Organizations. 2nd edition. New York: John Wiley \& Sons.

Kelley, R.E. (1988). In praise of followers. Harvard Business Review, (November-December), 142-149.

Keller, T., \& Dansereau, F. (1995). Leadership and empowerment: A social exchange perspective. Human Relations, 48, 127-146.

Kim, K.I., \& Organ, D.W. (1982). Determinants of leader-subordinate exchange relationships. Group E Organization Studies, 7, 77-89.

Klein, K.J., Dansereau, F., \& Hall, R.J. (1994). Levels issues in theory development, data collection and analysis. Academy of Management Review, 19(2), 195-229.

Kozlowski, SW., \& Doherty, M.L. (1989). Integration of climate and leadership: Examination of a neglected issue. Journal of Applied Psychology, 74, 546-553.

LaGrace, R.R., (1990). Leader-member exchange: Antecedents and consequences of the cadre and hired hand. Journal of Personal Selling and Sales Management, 10, 11-19.

Larwood, L., \& Blackmore, J. (1978). Sex discrimination in managerial selection: Testing predictions of the vertical dyad linkage model. Sex Roles, 4, 359-367.

Liden, R.C. (1985). Female perceptions of female and male managerial behavior. Sex Roles, $12,421-432$.

Liden, R., \& Graen, G.B. (1980). Generalizability of the vertical dyad linkage model of leadership. Academy of Management Journal, 23, 451-465.

Liden, R.C., \& Maslyn, J.M. (1993). Scale development of a MDM measure of LMX. Paper presented at the Academy of Management annual meeting, Atlanta, GA.

Liden, R.C., \& Mitchell, T.R. (1989). Ingratiation in the development of leader-member exchanges. In: R.A. Giacalone \& P. Rosenfeld (Eds.), Impression Management in the Organization (pp. 343-361). Hillsdale, NJ: Lawrence Erlbaum.

Liden, R.C., Wayne, S.J., Bradway, L.K., Jr., Murphy, S. (1994). A field investigation of individual empowerment, group empowerment, and task interdependence. Paper presented at the National Academy of Management Meeting, Dallas, TX.

Liden, R.C., Wayne, S.J., \& Stilwell, D. (1993). A longitudinal study on the early development of leader-member exchange. Journal of Applied Psychology, 78, 662-674.

Manogran, P., \& Conlon, E.J. (1993). A leader-member exchange approach to explaining organizational citizenship behavior. Proceedings of the Annual Meeting of the Academy of Management (pp. 249-253). Atlanta, GA.

Manogran, P., Stauffer, J., \& Conlon, E.J. (1994). Leader-member exchange as a key mediating variable between employee's perceptions of fairness and organizational citizenship behavior. Paper presented at the Academy of Management annual meeting, Dallas, TX.

Mansour-Cole, D. (1993). Perceived fairness in the work place. Unpublished Ph.D. dissertation, Department of Management, University of Cincinnati.

McClane, W.E. (1991a). The interaction of leader and member characteristics in the leadermember exchange model of leadership. Small Group Research, 22, 283-300.

McClane, W.E. (1991b). Implications of member role differentiation: Analysis of a key concept in the LMX model of leadership. Group \& Organization Studies, 16, 102-113.

Meindl, J.R., Erlich, S.B., \& Dukerich, J.M.(1985). The romance of leadership. Administrative Science Quarterly, 30, 78-102.

Mitchell, T. (1983). The effects of social, task, and situational factors on motivation, performance, and appraisal. In: F. Landy, S. Zedeck, \& J. Cleveland (Eds.), Performance Measurement and Theory (pp. 39-59). Hillsdale, NJ: Erlbaum. 
Nystrom, P.C. (1990). Organizational commitment. Group \& Organization Studies, 5, 296-312.

Phillips, R.L., Duran, C.A., \& Howell, R.D. (1993). An examination of the multidimensionality of leader-member exchange. Paper presented at the Southern Management Association Meetings, Atlanta, GA.

Podsakoff, P.M., MacKenzie, S.B., \& Hui, C. (1993). Organizational citizenship behaviors and managerial evaluations of employee performance: A review and suggestions for future research. In: G.R. Ferris (Ed.), Research in Personnel and Human Resources Management (Vol. 11, pp. 1-40). Greenwich, CT: JAI Press.

Ridolphi, J., \& Seers, A. (1984). Leader behavior versus leader-member exchange: A competitive test. Paper presented at the Southeast Decision Sciences meeting, Williamsburg, VA.

Rosse, J.G., \& Kraut, A.I. (1983). Reconsidering the vertical dyad linkage model of leadership. Journal of Occupational Psychology, 56, 63-71.

Rousseau, D. (1985). Issues of level in organizational research: Multilevel and cross-level perspectives. In: L.L. Cummings \& B.M. Staw (Eds.) Research in Organizational Behavior (vol. 7, pp. 1-37). Greenwich, CT: JAI Press.

Scandura, T. (1995). Leader-member exchange model of leadership and fairness issues. Unpublished manuscript.

Scandura, T., \& Graen, G.B. (1984). Moderating effects of initial leader-member exchange status on the effects of a leadership intervention. Journal of Applied Psychology, 69, 428-436.

Scandura, T.A., Graen, G.B., \& Novak, M.A. (1986). When managers decide not to decide autocratically. Journal of Applied Psychology, 71, 106.

Schiemann, W.A. (1977). Structural and interpersonal effects on patterns of managerial communications: A longitudinal investigation. Unpublished Ph.D. dissertation, University of Illinois.

Schiemann, W.A., \& Graen, G.B. (1984). Structural and interpersonal effects in patterns of managerial communication. Unpublished manuscript, Department of Management, University of Cincinnati.

Schriesheim, C.A., \& Gardiner, C.C. (1992). An exploration of the discriminant validity of the leader-member exchange scale (LMX 7) commonly used in organizational research. Paper presented at the Southern Management Association Meeting, New Orleans, LA.

Schriesheim, C.A., Neider, L.L., Scandura, T.A., \& Tepper, B.J. (1992). Development and preliminary validation of a new scale (LMX-6) to measure leader-member exchange in organizations. Educational and Psychological Measurement, 52, 135-147.

Scott, S. (1993). The influence of climate perceptions on innovation behavior. Unpublished Ph.D. dissertation, Department of Management, University of Cincinnati.

Seers, A. (1981). A dual attachment concept: A longitudinal investigation of the combination of characteristic (JC) enhancement and leader-member exchange (LMX) offer to all members. Unpublished Ph.D. dissertation (S. Rains Wallace award finalist), University of Cincinnati.

Seers, A., \& Graen, G.B. (1984). The dual attachment concept: A longitudinal investigation of the combination of task characteristics and leader-member exchange. Organizational Behavior \& Human Performance, 33, 283-306.

Skinner, B.F. (1953). Science and Human Behavior. New York: Macmillan.

Snyder, R.A., \& Bruning, N.S. (1985). Quality of vertical dyad linkages: Congruence of supervisor and subordinate competence and role stress as explanatory variables. Group $\mathcal{E}$ Organization Studies, 10, 81-94. 
Snyder, R.A., Williams, R.R., \& Cashman, J.F. (1984). Age, tenure, and work perceptions as predictors of reactions to performance feedback. Journal of Psychology, 116, 11-21.

Steiner, D.D. (1988). Value perceptions in leader-member exchange. Journal of Social Psychology, 128, 611-618.

Stepina, L.P., Perrewe, P.L., \& Hassell, B.L. (1991). A comparative test of the independent effects of interpersonal, task, and reward domains on personal and organizational outcomes. Journal of Social Behavior and Personality, 6, 93-104

Tierney P. (1992). The contribution of leadership, supportive environment, and individual attributes to creative performance: A quantitative field study. Unpublished Ph.D. dissertation, Department of Management, University of Cincinnati.

Tsui, AS., \& Egan, T.D. (1994). Performance implications of relational demography in vertical dyads. Paper presented at the Academy of Management annual meeting, Dallas, TX.

Tsui, A.S., Xin, K.R., \& Egan, T.D. (1994). Relational demography: The missing link in vertical dyad linkage. Paper presented at the American Psychological Association Conference on Diversity, Greensboro, NC.

Turban, D.B., Jones, A.P., \& Rozelle, R.M. (1990). Influences of supervisor liking of a subordinate and the reward context on the treatment and evaluation of that subordinate. Motivation and Emotion, 14, 215-233.

Uhl-Bien, M., \& Graen, G.B. (1992). Self-management and team-making in cross-functional work teams: Discovering the keys to becoming an integrated team. Journal of High Technology Management, 3, 225-241.

Uhl-Bien, M., \& Graen, G.B. (1993a). Leadership-making in self-managing professional work teams: An empirical investigation. In: K.E. Clark, M.B. Clark, \& D.P. Campbell (Eds.), The Impact of Leadership (pp. 379-387). West Orange, NJ: Leadership Library of America.

Uhl-Bien, M., \& Graen, G.B. (1993b). Toward a contingency model of empowerment: Contribution of self-management empowerment and leadership-making empowerment to uni-functional and multi-functional professional work unit performance. Paper presented at the National Academy of Management Meeting, Atlanta, GA.

Uhl-Bien, M., Tierney, P.S., Graen, G.B., \& Wakabayashi, M. (1990). Company paternalism and the hidden-investment process: Identification of the "right type" for line managers in leading Japanese organizations. Group \& Organization Studies, 15, 414-430.

Vasudevan, D. (1993). Developing a model for predicting the career intentions of undergraduate engineering students. Unpublished Ph.D. dissertation, Department of Management, University of Cincinnati.

Vecchio, R.P. (1982). A further test of leadership effects due to between-group and withingroup variation. Journal of Applied Psychology, 67, 200-208.

Vecchio, R.P. (1987). Situational leadership theory: An examination of a prescriptive theory. Journal of Applied Psychology, 72, 444-451.

Vecchio, R.P., \& Gobdel, B.C. (1984). The vertical dyad linkage model of leadership: Problems and prospects. Organizational Behavior \& Human Performance, 34, 5-20.

Vecchio, R.P., Griffeth, R.W., \& Horn, P.W., (1986). The predictive utility of the vertical dyad linkage approach. Journal of Social Psychology, 126, 617-625.

Wakabayashi, M., \& Graen, G.B. (1984). The Japanese career progress study: A 7-year follow-up. Journal of Applied Psychology, 69, 603-614 .

Wakabayashi, M., \& Graen, G.B. (1988). Human resource development of Japanese managers: Leadership and career investment. In: K. Rowland \& G. Ferris (Eds.), International Human Resources Management (Supplement 1). Greenwich, CT: JAI Press. 
Wakabayashi, M., Graen, G.B., Graen, M.R., \& Graen, M.G. (1988). Japanese management progress: Mobility into middle management. Journal of Applied Psychology, 73, 217-227.

Wakabayashi, M., Graen, G.B., \& Uhl-Bien, M. (1990). Generalizability of the hidden investment hypothesis among line managers in five leading Japanese corporations. $\mathrm{Hu}$ man Relations, 43, 1099-1116.

Wakabayashi, M., Minami, T., Hashimoto, M., Sano, K., Graen, G.B., \& Novak, M. (1980). Managerial career development: Japanese style. International Journal of Intercultural Relations, 4, 391-420.

Waldron, V.R. (1991). Achieving communication goals in superior-subordinate relationships: The multi-functionality of upward maintenance tactics. Communication Monographs, 58, 289-306.

Wayne, S.J., \& Ferris, G.R. (1990). Influence tactics, affect, and exchange quality in supervisory-subordinate interactions: A laboratory experiment and a field study. Journal of Applied Psychology, 75, 487-499.

Weitzel, J.R., \& Graen, G.B. (1989). System development project effectiveness: Problemsolving competence as a moderator variable. Decision Sciences, 20, 507-531.

Weick, K. (1969). The Social Psychology of Organizing. Reading, MA: Addison-Wesley.

Yammarino, F.J., \& Dubinsky, A.J. (1992). Superior-subordinate relationships: A multiple levels of analysis approach. Human Relations, 45, 575-600.

Yukl, G. (1989). Leadership in Organizations. (2nd edition. Englewood Cliffs, NJ: Prentice-Hall.

Zalesny, M.D., \& Graen, G.B. (1987). Exchange theory in leadership research. In: A. Kieser, G. Reber, \& R. Wanderer (Eds.), Handbook of Leadership (pp. 714-727). Stuttgart, Germany: C.E. Paeschel, Verlag. 